\title{
Studies on Correlation and Path Coefficient Analyses in Brinjal (Solanum melongena L.)
}

\author{
Ram Ashish Gupta ${ }^{1}$, C. N. Ram ${ }^{1 *}$, Satish Kr. Chakravati ${ }^{2}$, Chandra Deo ${ }^{1}$, \\ M. K. Vishwakarma ${ }^{3}$, D. K. Gautam ${ }^{1}$ and Pushpendra Kumar ${ }^{1}$ \\ ${ }^{1}$ Department of Vegetable Science, (N.D.U.A \& T, Kumarganj, Faizabad U.P.), India \\ ${ }^{2}$ Krishi Vigyan Kendra, Bahraich (N.D.U.A \& T, Kumarganj, Faizabad U.P.), India \\ ${ }^{3}$ Department of Genetics and Plant Breeding, BHU, Varanasi, 221005, India \\ *Corresponding author
}

\begin{abstract}
A B S T R A C T
Keywords

Genetic

divergence,

correlation and

path coefficient

analyses.

Article Info

Accepted:

31 June 2017

Available Online:

10 July 2017

Genetic studies in terms of correlation and path coefficient analysis were studied for10 quantitative characters of thirty-two genotypes of brinjal (Solanum melongena L.).Total yield per plant had exhibited highly significant and positive association with marketable fruit yield per plant, fruit weight, fruit weight per plant and fruit circumference and significant association with marketable fruit yield per plant. High magnitude of positive direct effect on fruit yield was exerted by marketable fruit yield per plant followed by fruit weight and fruits per plant. The negative direct effects on yield was showed by fruit circumference and plant height but were substantially low. Marketable fruit yield per plant was found to have substantial positive indirect effect for fruit weight, fruit circumference and fruits per plant. Direct selection may be carried out considering these traits as the main selection criteria to cut down indirect effects of the other characters throughout the development of high-yielding eggplant varieties.
\end{abstract}

\section{Introduction}

Brinjal or eggplant (Solanum melongena L.) is one of the important solanaceous vegetable crop having diploid chromosome number $2 \mathrm{n}=2 \mathrm{x}=24$. One hundred gram edible portion of brinjal fruit contains $92.7 \%$ moisture, $24.0 \%$ calories, $4.0 \%$ carbohydrates, $1.4 \mathrm{~g}$ protein, $0.3 \mathrm{~g}$ fats, $1.3 \mathrm{~g}$ fibers, 124.0 (I.U.) vitamin A and $12.0 \mathrm{mg}$ vitamin $\mathrm{C}$ (Chen and $\mathrm{Li}, 1996)$. It also contains $52.0 \mathrm{mg}$ chlorine, $47.0 \mathrm{mg}$ phosphorus, $44.0 \mathrm{mg}$ sulfur and other minerals (Aykroyd, 1963). Brinjal contains certain medicinal properties like white brinjal is said to be good for diabetic patients
(Choudhary, 1976). Fried Brinjal fruit in Til oil is used to cure toothache (Chen and $\mathrm{Li}$, 1996). It has also been recommended as an excellent remedy for those suffering from a liver complaint.

Estimation of correlation coefficient among the yield contributing characters is necessary to understand the direction of selection and maximize yield in the shortest period. Path co-efficient provides an efficient way of entangling direct and indirect causes of association of selection and measures the 
relative importance of each causal factor. Yield is a composite character and dependent upon a number of ascribes. For an effective selection, it is essential to have the association of various attributes with yield and yield attributing characters. Several workers have done remarkable studies on this aspect. The relative contribution of causal factors cannot be measured by simple correlation hence would not be useful to the final yield. While the component traits are inter-dependent, they much affect their direct connection with yield and resultant limit the reliability of selection indices grounded upon correlation coefficients. The path coefficient analysis allows the detachment of direct effects from indirect effects via other related traits by dividing the genotypic correlation coefficients. Therefore, the present study was conducted to calculate the genotypic correlations to determine the indirect effects of component characters on yield in brinjal.

\section{Materials and Methods}

To assess the performance of thirty-two genotypes Randomized Complete Block Design was followed in three replications during Kharif season in 2014. Each treatment comprised of two rows and in each row, ten plants were maintained. Transplanting was done at a spacing of $60 \mathrm{~cm}$ between row to row and $45 \mathrm{~cm}$ plant to plant having net plot size of $4.5 \times 1.2 \mathrm{~m}^{2}$. For the data observation thirteen characters were considered viz. plant height $(\mathrm{cm})$, days to $50 \%$ flowering, primary branches per plant, fruit weight $(\mathrm{g})$, fruit circumference $(\mathrm{cm})$, fruits per plant, fruit length $(\mathrm{cm})$, marketable fruit yield per plant $(\mathrm{kg})$, unmarketable fruit yield per plant $(\mathrm{kg})$ and total fruit yield per plant $(\mathrm{kg})$. The simple correlations between different characters at genotypic (g) and phenotypic (p) levels were estimated according to Searle (1961). For the Path coefficient analysis, Dewey and $\mathrm{Lu}$ (1959) method was followed. Seed yield is not independent variable; it is influenced by all the other independent variables and characters, directly as well as indirectly. The variation in seed yield unexplained by the ten causes was presumed to be contributed by a residual factor effect $(\mathrm{x})$ which is uncorrelated with other factors. Path coefficients were estimated by solving the following simultaneous equation indicating the primary relationship between correlation and path coefficient.

\section{Results and Discussion}

\section{Correlation coefficient}

The nature and magnitude of the association between yield and its component traits are necessary for adequate selection in advance generations. Nature of population under consideration and the magnitude of correlation coefficient could often be influenced by choice of the individual upon which the observations are made. Correlations between character pairs are due to the linkage of genes or pleiotropy of genes. Therefore, selection of one trait influences the other linked or pleiotropically affected traits. Considerable importance has been attached to correlation studies in the plant improvement because they are helpful in making an effective selection. In the present study, correlations between nine characters were worked out in all possible combinations at phenotypic and genotypic levels as shown in (Table 1). In general, the magnitude of genotypic correlation coefficient was higher than the corresponding values of the phenotypic correlation coefficient. This indicated a strong genetic association between the traits and the phenotypic expression which was suppressed due to environmental influence. The current study also suggested that both genotypic and phenotypic correlation were similar in direction. Similar findings had also been reported by Sharma et al., (2000) and Goto (1953). 
Table.1 Estimates of phenotypic correlation coefficients among ten characters in brinjal germplasm

\begin{tabular}{|c|c|c|c|c|c|c|c|c|c|c|}
\hline $\begin{array}{l}\text { S. } \\
\text { No } \\
\text {. }\end{array}$ & Characters & $\begin{array}{c}\text { Plant } \\
\text { height } \\
\text { (cm) }\end{array}$ & $\begin{array}{c}\text { No of } \\
\text { primary } \\
\text { branche } \\
\text { s per } \\
\text { plant } \\
\end{array}$ & $\begin{array}{c}\text { Fruit } \\
\text { lengt } \\
\text { h } \\
(\mathrm{cm})\end{array}$ & $\begin{array}{c}\text { Fruit } \\
\text { circumference } \\
(\mathbf{c m})\end{array}$ & $\begin{array}{c}\text { No of } \\
\text { fruits } \\
\text { per } \\
\text { plant }\end{array}$ & $\begin{array}{c}\text { Averag } \\
\text { e fruit } \\
\text { weight } \\
\text { (g) }\end{array}$ & $\begin{array}{c}\text { Marketab } \\
\text { le fruit } \\
\text { yield per } \\
\text { plant }(k g)\end{array}$ & $\begin{array}{c}\text { Unmarketab } \\
\text { le fruit yield } \\
\text { per plant } \\
(\mathrm{kg})\end{array}$ & $\begin{array}{l}\text { Total fruit } \\
\text { yield per } \\
\text { plant (kg) }\end{array}$ \\
\hline 1. & Days to $50 \%$ flowering & 0.08 & 0.16 & -0.17 & $0.30 * *$ & -0.08 & $0.23 *$ & 0.16 & 0.06 & 0.18 \\
\hline 2. & Plant height $(\mathrm{cm})$ & & $0.44 * *$ & 0.07 & $0.20 *$ & -0.12 & $0.23 *$ & 0.14 & $0.20 *$ & 0.11 \\
\hline 3. & No. of primary branches per plant & & & 0.18 & 0.11 & 0.16 & 0.01 & 0.14 & 0.18 & 0.14 \\
\hline 4. & Fruit length $(\mathrm{cm})$ & & & & -0.12 & $0.29 * *$ & -0.19 & 0.06 & 0.10 & 0.06 \\
\hline 5. & Fruit circumference $(\mathrm{cm})$ & & & & & $-0.29 * *$ & $0.82 * *$ & $0.51 * *$ & $0.52 * *$ & $0.55 * *$ \\
\hline 6. & Number of fruits per plant & & & & & & $-0.44 * *$ & $0.32 * *$ & $0.25 *$ & $0.33 * *$ \\
\hline 7. & Average fruit weight $(\mathrm{g})$ & & & & & & & $0.62 * *$ & $0.48 * *$ & $0.64 * *$ \\
\hline 8. & Marketable fruit yield per plant $(\mathrm{kg})$ & & & & & & & & $0.66^{* *}$ & $0.96 * *$ \\
\hline 9. & $\begin{array}{l}\text { Unmarketable fruit yield per plant } \\
(\mathrm{kg})\end{array}$ & & & & & & & & & $0.72 * *$ \\
\hline
\end{tabular}

*, **-Significant at $5 \%$ and $1 \%$ probability level, respectively

Table.2 Estimates of genotypic correlation coefficients among ten characters in brinjal germplasm

\begin{tabular}{|c|c|c|c|c|c|c|c|c|c|c|}
\hline $\begin{array}{c}\text { S. } \\
\text { No. }\end{array}$ & Characters & $\begin{array}{c}\text { Plant } \\
\text { height } \\
(\mathrm{cm})\end{array}$ & $\begin{array}{c}\text { No of } \\
\text { primary } \\
\text { branches } \\
\text { per } \\
\text { plant } \\
\end{array}$ & $\begin{array}{l}\text { Fruit } \\
\text { length } \\
(\mathrm{cm})\end{array}$ & $\begin{array}{c}\text { Fruit } \\
\text { circumference } \\
(\mathbf{c m})\end{array}$ & $\begin{array}{c}\text { No of } \\
\text { fruits } \\
\text { per } \\
\text { plant }\end{array}$ & $\begin{array}{l}\text { Average } \\
\text { fruit } \\
\text { weight } \\
\text { (g) }\end{array}$ & $\begin{array}{c}\text { Marketable } \\
\text { fruit yield } \\
\text { per } \\
\text { plant(kg) }\end{array}$ & $\begin{array}{c}\text { Unmarketable } \\
\text { fruit yield per } \\
\text { plant (kg) }\end{array}$ & $\begin{array}{c}\text { Total } \\
\text { fruit } \\
\text { yield per } \\
\text { plant } \\
\text { (kg) }\end{array}$ \\
\hline 1. & Days to $50 \%$ flowering & 0.10 & 0.18 & -0.19 & 0.30 & -0.08 & 0.26 & 0.26 & 0.09 & 0.27 \\
\hline 2. & Plant height $(\mathrm{cm})$ & & 0.49 & 0.12 & 0.22 & -0.11 & 0.25 & 0.17 & 0.23 & 0.15 \\
\hline 3. & No. of primary branches per plant & & & 0.24 & 0.12 & 0.22 & 0.04 & 0.23 & 0.28 & 0.22 \\
\hline 4. & Fruit length $(\mathrm{cm})$ & & & & -0.13 & 0.30 & -0.21 & 0.08 & 0.11 & 0.05 \\
\hline 5. & Fruit circumference $(\mathrm{cm})$ & & & & & -0.31 & 0.87 & 0.59 & 0.56 & 0.62 \\
\hline 6. & Number of fruits per plant & & & & & & -0.48 & 0.30 & 0.22 & 0.31 \\
\hline 7. & Average fruit weight $(\mathrm{g})$ & & & & & & & 0.66 & 0.48 & 0.65 \\
\hline 8. & Marketable fruit yield per plant $(\mathrm{kg})$ & & & & & & & & 0.69 & 0.99 \\
\hline 9. & Unmarketable fruit yield per plant $(\mathrm{kg})$ & & & & & & & & & 0.73 \\
\hline
\end{tabular}


Table.3 Direct and indirect effect of nine characters on fruit yield per plant $(\mathrm{kg})$ at phenotypic level in brinjal

\begin{tabular}{|c|c|c|c|c|c|c|c|c|c|c|c|}
\hline $\begin{array}{l}\text { S. } \\
\text { No } \\
\text {. }\end{array}$ & Characters & $\begin{array}{c}\text { Days to } \\
\mathbf{5 0 \%} \\
\text { floweri } \\
\text { ng }\end{array}$ & $\begin{array}{c}\text { Plant } \\
\text { height } \\
(\mathrm{cm})\end{array}$ & $\begin{array}{c}\text { No of } \\
\text { primar } \\
y \\
\text { branch } \\
\text { es per } \\
\text { plant }\end{array}$ & $\begin{array}{c}\text { Fruit } \\
\text { lengt } \\
\text { h } \\
(\mathrm{cm})\end{array}$ & $\begin{array}{c}\text { Fruit } \\
\text { circumfer } \\
\text { ence }(\mathbf{c m})\end{array}$ & $\begin{array}{c}\text { No of } \\
\text { fruits } \\
\text { per } \\
\text { plant }\end{array}$ & $\begin{array}{c}\text { Averag } \\
\text { e fruit } \\
\text { weight } \\
\text { (g) }\end{array}$ & $\begin{array}{c}\text { Marketabl } \\
\text { e fruit } \\
\text { yield per } \\
\text { plant(kg) }\end{array}$ & $\begin{array}{c}\text { Unmarketa } \\
\text { ble } \\
\text { fruit yield } \\
\text { per plant } \\
\text { (kg) }\end{array}$ & $\begin{array}{c}\text { Total } \\
\text { fruit } \\
\text { yield } \\
\text { per } \\
\text { plant } \\
\text { (kg) }\end{array}$ \\
\hline 1. & Days to $50 \%$ flowering & $\mathbf{0 . 0 3}$ & -0.00 & 0.00 & -0.00 & -0.00 & -0.02 & 0.08 & 0.09 & 0.00 & 0.18 \\
\hline 2. & Plant height $(\mathrm{cm})$ & 0.00 & -0.03 & 0.00 & 0.00 & -0.00 & -0.03 & 0.08 & 0.08 & 0.01 & 0.11 \\
\hline 3. & No. of primary branches per plant & 0.00 & -0.01 & 0.00 & 0.00 & -0.00 & 0.04 & 0.00 & 0.08 & 0.01 & 0.14 \\
\hline 4. & Fruit length $(\mathrm{cm})$ & -0.00 & -0.00 & 0.00 & $\mathbf{0 . 0 1}$ & 0.00 & 0.07 & -0.07 & 0.04 & 0.00 & 0.06 \\
\hline 5. & Fruit circumference $(\mathrm{cm})$ & 0.01 & -0.00 & 0.00 & -0.00 & -0.02 & -0.07 & 0.29 & 0.31 & 0.04 & 0.55 \\
\hline 6. & Number of fruits per plant & -0.00 & 0.00 & 0.00 & 0.00 & 0.00 & 0.26 & -0.15 & 0.19 & 0.02 & 0.33 \\
\hline 7. & Average fruit weight $(\mathrm{g})$ & 0.00 & -0.00 & 0.00 & -0.00 & -0.01 & -0.11 & 0.35 & 0.38 & 0.04 & 0.64 \\
\hline 8. & Marketable fruit yield per plant(kg) & 0.00 & -0.00 & 0.00 & 0.00 & -0.01 & 0.08 & 0.22 & 0.60 & 0.05 & 0.96 \\
\hline 9. & Unmarketable fruit yield per plant $(\mathrm{kg})$ & 0.00 & -0.00 & 0.00 & 0.00 & -0.01 & 0.06 & 0.17 & 0.40 & 0.08 & 0.72 \\
\hline
\end{tabular}

$\mathrm{R}^{2}=0.9655$, Residual effect $=0.1858$

Table.4 Direct and indirect effect of nine characters on fruit yield per plant $(\mathrm{kg})$ at genotypic level in brinjal

\begin{tabular}{|c|c|c|c|c|c|c|c|c|c|c|c|}
\hline $\begin{array}{l}\text { S. } \\
\text { No } \\
\text {. }\end{array}$ & Characters & $\begin{array}{c}\text { Days to } \\
50 \% \\
\text { floweri } \\
\text { ng }\end{array}$ & $\begin{array}{l}\text { Plant } \\
\text { height } \\
(\mathrm{cm})\end{array}$ & $\begin{array}{c}\text { No of } \\
\text { primary } \\
\text { branche } \\
\text { s per } \\
\text { plant } \\
\end{array}$ & $\begin{array}{c}\text { Fruit } \\
\text { lengt } \\
\text { h } \\
(\mathrm{cm})\end{array}$ & $\begin{array}{c}\text { Fruit } \\
\text { circumferen } \\
\text { ce }(\mathbf{c m})\end{array}$ & $\begin{array}{c}\text { No of } \\
\text { fruits } \\
\text { per } \\
\text { plant }\end{array}$ & $\begin{array}{l}\text { Averag } \\
\text { e fruit } \\
\text { weight } \\
\text { (g) }\end{array}$ & $\begin{array}{c}\text { Marketable } \\
\text { fruit yield } \\
\text { per plant } \\
\text { (kg) }\end{array}$ & $\begin{array}{l}\text { Unmarket } \\
\text { able fruit } \\
\text { yield per } \\
\text { plant (kg) }\end{array}$ & $\begin{array}{c}\text { Total } \\
\text { fruit } \\
\text { yield per } \\
\text { plant } \\
\text { (kg) } \\
\end{array}$ \\
\hline 1. & Days to $50 \%$ flowering & -0.36 & 0.01 & -0.00 & 0.07 & 0.47 & 0.22 & -1.25 & 1.11 & -0.00 & 0.27 \\
\hline 2. & Plant height $(\mathrm{cm})$ & -0.03 & 0.10 & -0.00 & -0.04 & 0.34 & 0.32 & -1.24 & 0.74 & -0.02 & 0.15 \\
\hline 3. & No. of primary branches per plant & -0.06 & 0.05 & -0.01 & -0.09 & 0.19 & -0.60 & -0.20 & 0.98 & -0.02 & 0.22 \\
\hline 4. & Fruit length $(\mathrm{cm})$ & 0.07 & 0.01 & -0.00 & -0.38 & -0.20 & -0.84 & 1.05 & 0.36 & -0.01 & 0.05 \\
\hline 5. & Fruit circumference $(\mathrm{cm})$ & -0.11 & 0.02 & -0.00 & 0.05 & 1.54 & 0.87 & -4.24 & 2.54 & -0.05 & 0.62 \\
\hline 6. & Number of fruits per plant & 0.03 & -0.01 & -0.00 & -0.11 & -0.49 & -2.72 & 2.35 & 1.30 & -0.02 & 0.31 \\
\hline 7. & Average fruit weight(g) & -0.09 & 0.02 & -0.00 & 0.08 & 1.35 & 1.32 & -4.83 & 2.83 & -0.04 & 0.65 \\
\hline 8. & Marketable fruit yield per plant(kg) & -0.09 & 0.01 & -0.00 & -0.03 & 0.92 & -0.82 & -3.20 & 4.28 & -0.06 & 0.99 \\
\hline 9. & $\begin{array}{l}\text { Unmarketable fruit yield per } \\
\text { plant }(\mathrm{kg})\end{array}$ & -0.03 & 0.02 & -0.00 & -0.04 & 0.88 & -0.60 & -2.36 & 2.97 & -0.09 & 0.73 \\
\hline
\end{tabular}

$\mathrm{R}^{2}=1.0628$, Residual effect $=$ SQRT [1-1.0628] 
A study of data (Tables 1 and 2) revealed that most important traits total fruit yield per plant had highly significant and positive association with marketable fruit yield per plant, fruit weight, fruits per plant, and fruit circumference at both phenotypic and genotypic level. Thus, these characters emerged as most important associates of fruit yield in brinjal. The available literature has also indicated correlation between total fruit yield per plant and character mentioned above in brinjal.

Marketable fruit yield per plant, fruit weight; fruit per plant, fruit circumference and total fruit yield per plant were found significantly and positively correlated among themselves. Fruit weight is significantly but negatively correlated with fruits per plant while positively and significantly correlated with fruit circumference and plant height. Primary branches per plant were significantly and positively correlated with plant height suggesting, therefore, selection for marketable yield per plant, fruits weight, fruit per plant and fruit circumference will be helpful for yield improvement. Association of either of these traits with yield has also been reported by Pathania et al., (2005), Nair and Mehta (2007), Jadhao (2009); Muniappan (2010) and Karak et al., (2012).

\section{Path coefficient analysis}

Path coefficient is simply standardized partial regression coefficient which splits the correlation coefficient into the measures of the direct and indirect effects of a set of independent variables on the dependent variable. This analysis provides a method for separating out the direct and indirect effect of causal factors which affect the yield. The present study on path coefficient analysis revealed that the highest magnitude of positive direct affect on yield per plant was exerted by marketable fruit yield per plant followed by fruit weight and fruits per plant at both phenotypic and genotypic level (Tables 3 and 4). This indicates that direct selection based on marketable fruit yield per plant and fruit weight would result in an appreciable improvement of yield per plant. The negative direct effect on yield was shown by fruit circumference (-0.02) and Plant height (0.03 ), but were substantially low. Marketable fruit yield per plant was not only found to have maximum direct effect on total fruit yield per plant, but it also contributed substantial positive indirect effect for fruit weight (0.38), followed by fruit circumference (0.31) and fruits per plant (0.19), and days to $50 \%$ flowering (0.09), towards total fruit yield per plant. Therefore, during selection, these characters should also be taken into consideration. Similar results had also been reported by (Naliyadhara et al., 2007; Mishra et al., 2007; Bansal and Mehta, 2008; Muniappan et al., 2010; Thangamani and Jansirani, 2012).

\section{Acknowledgment}

The work on brinjal reported in this paper has been supported by research and teaching faculties of Department of Vegetable Science, N.D.U.A.T and We would also like to thank Mr. Murli Mohan Khetan for statistical analysis.

\section{References}

Aykroyd, W. R. (1963). The nutritive value of Indian foods and planning of satisfactory diet. I.C.M.R. Special Rep. Series. No. 42.

Bansal, S. and Mehta, A.K. (2008). Phenotypic correlation and path coefficient analysis of some quantitative traits in eggplant. Indian $J$ Trop. Biodiversity. 16 (2):185-190.

Chen, N. C. and Li, H. M. (1996). Cultivation and Seed Production of Eggplant. 
AVRDC, Annual Publication, 203 (64): 246-261.

Choudhary, B. (1976). Vegetable, $4^{\text {th }}$ edn.National Book Trust, New Delhi, pp. 50-58.

Dewey, D. R. and Lu, K. H. (1959). A correlation and path coefficient analysis of components of crested wheat grass seed production. Agron. J., 51: 515-518.

Goto, K. (1953). Genetic studies on eggplant. Genetics, 2b:445-412.

Jadhao, S. T.; Thaware, B. L.; Rathod, D. R. and Navhale, V. C. (2009). Correlation and path analysis studies in brinjal. Ann. Plant Physiol. 23 (2): 177-179.

Karak, C.; Ray, U.; Akhtar, S.; Naik, A. and Hazra, P. (2012).Genetic variation and character association in fruit yield components and quality characters in brinjal [Solanum melongena L.]. J. Crop and Weed. 8 (1): 86-89.

Mishra, S.V.; Warade, S.D and. Nayakwadi, M.B. (2007). Correlation and path coefficient analysis in brinjal. $J$. Maharashtra Agri. Univ.; 32(1):74-76.

Muniappan, S.; Saravan, K. and Ramya, B. (2010). Study on genetic divergence and variability for certain economic characters in eggplant (Solanum melongena L.). Electronic J. Pl.Breed.,
1(4): 462-465.

Nair, R. and Mehta, A. K. (2007). Phenotypic correlation and path coefficient analysis for some metric traits in brinjal (Solanum melongena L.). Asian J. Horti.; 2(2):164-168.

Naliyadhara, M. V.; Golani, I. J.; Mehta, D. R. and Purohit, V. L. (2007). Genetic variability, correlation co-efficient and path analysis in brinjal. Orissa J. Hort.; 35(2):92-96.

Pathania, N.K.; Katoch, R. and Katoch, V. (2005). Correlation and path analysis for some biometric traits in brinjal. Ann. Bio., 21 (2): 193-197.

Searle, S.M. (1961). Phenotypic, genotypic and environmental correlations. Biometrics, 17(7): 474-480.

Sharma, T.V.R.S.; Kishan, S. and Swaroop, K. (2000). Genetic variability and character association in brinjal (Solanum melongena L.). Indian. J. Hort., 57 (1): 59-65.

Thangamani, C. and Jansirani, P. (2012). Correlation and path coefficient analysis studies on yield and attributing characters in brinjal (Solanum melongena L.). Ele. J. Pl. Bred. 3(3):939-944.

\section{How to cite this article:}

Ram Ashish Gupta, C.N. Ram, Satish Kr. Chakravati, Chandra Deo, M.K. Vishwakarma, D.K. Gautam and Pushpendra Kumar. 2017. Studies on Correlation and Path Coefficient Analyses in Brinjal (Solanum melongena L.). Int.J.Curr.Microbiol.App.Sci. 6(7): 4543-4548. doi: https://doi.org/10.20546/ijcmas.2017.607.474 